\title{
Pengaruh Limbah Industri Batik Menggunakan Pewarna Alami dari Desa Wukirsari terhadap Viabilitas Bakteri Tanah
}

\section{Effect of the Waste of Industrial Batik using Natural Dye from Wukirsari on Soil Baceria Viability}

\author{
Yanisworo Wijaya Ratih ${ }^{1 *}$, Purwono Budi Santosa ${ }^{1}$ dan Eni Muryani ${ }^{2}$

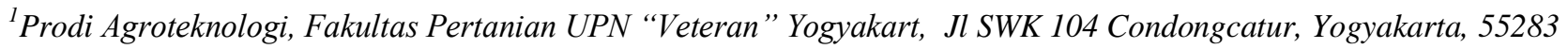 \\ Indonesia \\ ${ }^{2}$ Prodi Teknik Lingkungan, Fakultas Kebumian UPN “Veteran” Yogyakart, Jl SWK 104 Condongcatur, Yogyakarta, 55283 \\ Indonesia
}

\author{
Artikel histori : \\ Diterima November 2016 \\ Diterima dalam revisi November 2016 \\ Diterima Desember 2016 \\ Online Juni 2017
}

\begin{abstract}
ABSTRAK: Industri batik menggunakan pewarna alami sedang berkembang. Pewarna alami diperoleh dengan melakukan ekstraksi pada beberapa tanaman seperti jolawe (Terminalia bellirica), mahoni (Swieteniamacrophylla mahoni) dan indigo (Indigofera tinctoria). Beberapa tanaman penghasil pewarna alami sering digunakan sebagai antibiotik alami karena mampu menghambat pertumbuhan mikrobia. Kemampuan senyawa tersebut menghambat pertumbuhan mikrobia perlu diwaspadai karena ada kemungkinan bahwa paparannya dalam tanah dapat mengurangi populasi mikrobia. Penelitian ini mempunyai tujuan untuk mengetahui pengaruh limbah industri batik pewarna alami terhadap viabilitas bakteri tanah. Pengujian viabilitas sel dilakukan dengan mengamati pertumbuhan bakteri total, penambat nitrogen dan pelarut fosfat dalam tanah yang ditambah dengan masing-masing limbah jolawe, indigo, mahoni dan limbah pewarna campuran. Limbah dan tanah yang digunakan berasal dari desa Wukirsari, Imogiri, Kabupaten Bantul, DIY. Dilakukan pula karakterisasi terhadap limbah dan tanah yang digunakan. Parameter utama yang diamati meliputi jumlah sel bakteri total, penambat nitrogen dan pelarut fosfat, $\mathrm{pH}$, serta kadar fenolik dan flavonoid. Jumlah bakteri total, penambat nitrogen dan pelarut fosfat diamati dengan metode taburan berturut-turut dalam media nutrien agar, Jensen's dan Pikovskaya, sedangkan fenolik dan flavonoid dianalisis menggunakan metode spetrofotometrik. Hasil penelitian menunjukkan bahwa limbah meningkatkan $\mathrm{pH}$ tanah dari 5 menjadi 6,7. Kadar flavonoid dan fenolik limbah berturut-turut berkisar antara $0,14 \%$ sampai dengan $0,70 \%$ dan $0,18 \%$ sampai dengan $1,76 \%$. Viabilitas sel bakteri tidak dipengaruhi oleh kadar flavonoid dan fenolik limbah. Pada umumnya limbah batik pewarna alami tidak menurunkan viabilitas bakteri tanah..
\end{abstract}

Kata Kunci: limbah; pewarna alam; viabilitas; bakteri

ABSTRACT: The Batik industrial with natural dye is developing. Natural dyes are obtained from extracting of some plants, i.e. jolawe (Terminalia bellirica), mahoni (Swieteniamacrophylla mahoni) dan indigo (Indigofera tinctoria). These plants have antimicrobial effects and have been used as a traditional medicine. Discharge of waste of natural dye in the environment should be controlled because their antimicrobial effects might reduce the soil microbiol population. The present study was conducted to described the effect of the waste of batik industrial using natural dye on soil bacterial viability. The cells viability were observed based on growth of bacteria on soil added waste of batik industrial with natural dye. The parameters which were analyzed were characters of the soil and waste and populations of the total, solubilizing phosphate and fixing nitrogen bacteria. The number cells of total bacteria, solubilizing bacteria, and fixing nitrogen bacteria were analyzed using pour plate method on nutrient, Picovskaya's, and Jenssen's agar medium, respectively. Phenolics and flavonoids compounds were determined using spektrofotometer. The results shows that addition of waste of batik industrial with natural dye increase the soil $\mathrm{pH}$, from 5 to 6.7. The concentrations of phenolics and flavonoids of waste ranges from 0,14 to $0,70 \%$ and from 0,18 to $1,76 \%$, respectively. The viability of soil bacteria were not under the influence of Phenolics

*Corresponding Author:

Email: woro.yanis@yahoo.com 
and flavonoids concentrations. In general, waste of batik industrial with natural dye does not decrease the viability of soil bacteria.

Keywords: waste; natural dye; viability; bacteria

\section{Pendahuluan}

Industri batik berkembang pesat karena tren pakaian batik sedang diminati oleh semua kalangan. Sentra industri batik dengan pewarna alami muncul di beberapa daerah. Banyak kalangan menyebutkan bahwa batik yang diproduksi dengan pewarna alami menghasilkan limbah yang bersifat ramah bagi lingkungan dan aman untuk kesehatan. Benarkah limbah hasil pengolahan batik dengan pewarna alami bersifat ramah lingkungan? Secara kimiawi pewarna alami merupakan senyawa poliaromatis berbasis benzen. Pada umumya senyawa berbasis benzene relatif susah dirombak. Beberapa senyawa pewarna bersifat menghambat pertumbuhan jamur dan bakteri, sehingga sering digunakan sebagai antibiotik alami. Salah satu faktor pembatas pewarna alam adalah kemampuannya yang kurang dalam mewarnai kain serta tidak tahan terhadap garam yang dipakai dalam pencucian sehingga warna mudah mengalami pelunturan. Untuk mengatasi hal tersebut maka selama pewarnaan dilakukan proses yang disebut dengan mordanting menggunakan senyawa mordan dan fiksasi. Beberapa mordan yang efektif dan sering digunakan mengandung logam: (Al2(SO4)3), $\mathrm{KAl}\left(\mathrm{SO}_{4}\right)_{2}, \mathrm{~K}_{2} \mathrm{Cr}_{2} \mathrm{O}_{7}, \mathrm{FeSO}_{4}, \mathrm{CuSO}_{4}$ dan $\mathrm{SnCl}_{2}$ (Prabhu and Buthe, 2012). Dengan demikian apabila tidak dilakukan dengan hati-hati, proses mordanting berpotensi menimbulkan efek negatif bagi lingkungan. Tergantung dari jenis kain yang akan diwarnai dan jenis pewarnanya, mordanting membutuhkan $\mathrm{pH}$ tertentu, sehingga pada saat mordanting kadang ditambahkan pula senyawa basis. Hal ini mengakibatkan $\mathrm{pH}$ limbah pewarnaan batik bersifat basa. Pemaparan limbah di alam akan berdampak terhadap perubahan $\mathrm{pH}$ lingkungan. Di sentra industri batik dengan pewarna alam seperti di Wukirsari, pada umumnya limbah produksi batik langsung dibuang dalam sumur resapan tanpa diberi perlakuan tertentu. Dengan demikian limbah berpotensi mencemari sumber-sumber air. Hal ini perlu mendapat perhatian khusus, karena dampak pencemaran mungkin terasa beberapa puluh tahun kemudian. Penelitian ini mempunyai tujuan mengetahui keamanan limbah di dalam tanah dengan mempelajari pengaruh limbah industri batik pewarna alami terhadap viabilitas bakteri tanah. Dalam penelitian ini, limbah yang akan diuji dipilih berdasarkan jenis pewarna yang sering digunakan dalam industri batik pewarna alam di Wukirsari, yaitu ekstrak tanaman jolawe (Terminalia bellirica), mahoni (Swieteniamacrophylla mahoni) dan indigo (Indigofera tinctoria), serta limbah campuran. Dalam penelitian ini, jenis mikrobia alam yang akan diuji viabilitasnya adalah bakteri total serta bakteri yang berperanri penting dalam pertanian yaitu bakteri penambat nitrogen dan bakteri pelarut fosfat. Lebih dari $80 \%$ nitrogen terdapat di atmosfer, namun tidak dapat dimanfaatkan tanaman secara langsung. $\mathrm{N}$ udara perlu dikonversi terlebih dahulu menjadi amonia. Bakteri penambat nitrogen adalah bakteri yang mampu mereduksi $\mathrm{N}_{2}$ menjadi amonia $\left(\mathrm{NH}_{3}\right)$ yang dapat dimanfaatkan tanaman. Unsur P merupakan elemen utama dalam tanaman namun dalam tanah di daerah tropikal, P terlarut biasanya terdapat dalam jumlah yang sangat rendah (Saharan dan Nehra, 2011). P total dapat mencapai jumlah 400-1200 mg. kg2 tanah, namun konsentrasi $\mathrm{P}$ terlarut dalam tanah biasanya sangat rendah, kurang dari $1 \mathrm{ppm}$. Sel tanaman menyerap $\mathrm{P}$ dalam bentuk $\mathrm{H}_{2} \mathrm{PO}_{4}^{-}$atau $\mathrm{HPO}_{4}^{-2}$ yang bersifat terlarut. Mikroorganisme memegang peranan penting dalam proses pelarutan $\mathrm{P}$ anorganik tidak terlarut menjadi $\mathrm{P}$ terlarut (tersedia) bagi tanaman (Rodríguez dan Fraga, 1999; Saharan dan Nehra, 2011).

\section{Metode Penelitian}

Limbah dan tanah yang digunakan dalam penelitian di ambil dari desa Wukirsari, Imogiri, Bantul, Daerah Istimewa Yogyakarta. Dilakukan analisis kimiawi (BOD, $\mathrm{COD}, \mathrm{pH}, \mathrm{BO}$, flavanoid, fenolik, kadar logam: Al, Fe, Cr, dan $\mathrm{Ca}$, serta jumlah bakteri) terhadap limbah. Analisis fenolik dilakuan secara spektrofotometrik pada panjang gelimbang $760 \mathrm{~nm}$ menggunakan reagen Folin-Ciocalteau dengan asam gallac sebagai internal standart. Flavanoid dianalisis menggunakan metode kolorimetri aluminium chloride pada panjang gelombang $415 \mathrm{~nm}$, dengan internal standart berupa lutin (Chang et al., 2002; Atanassova and Christova-Bagdassarian, 2009; Chet, 2009; Huo et al., 2011, Baisha et al., 2012; Carlsen et al., 2012). COD dianalisis menggunakan metode kolorimetri. BOD diamati menggunakan metode Wrinkler. Kadar logam diamati menggunakan AAS. Jumlah bakteri diamati secara taburan pada media Nutrien agar. Tanah dianalisis kadar bahan organik, $\mathrm{pH}$ serta jumlah bakterinya. Pengujian pengaruh limbah terhadap viabilitas bakteri tanah dilakukan dengan cara mengatur kelembabannya pada $75 \%$ WHC menggunakan limbah batik pewarna alami jolawe, mahoni, indigo, dan campuran. Masing-masing kadar limbah yang digunakan adalah 0, 50 serta $100 \%$. Selanjutnya tanah diinkubasikan selama 30 hari. Selanjutnya jumlah bakteri total diamati secara taburan pada media Nutrien Agar, bakteri penambat nitrogen menggunakan medium bebas $\mathrm{N}$, Jensen's, sedangkan bakteri pelarut fosfat menggunakan medium Pikovskaya. Pengamatan dilakukan pada hari inkubasi 0, 7, 14 dan 21 hari (Grover, 2003; Nenwani et al., 2010), (Belimov et al., 1995; Sachdev et al., 2009) .

\section{Hasil dan Pembahasan}

Hasil analisis terhadap sifat kimiawi limbah disajikan pada tabel 1. Sesuai dengan Keputusan Menteri KLH no.03/MENKLH/H/1991 tentang baku mutu air limbah 
industri, parameter logam menunjukkan bahwa limbah termasuk dalam kategori baik-sedang. Namun demikian berdasarkan nilai BOD dan COD maka limbah termasuk dalam kategori kurang baik. Logam yang terdapat dalam limbah kemungkinan berasal dari penggunaan mordan berupa tawas (Al2(SO4)3), kapur (CaCO3), tunjung (FeSO4), dan krom $\left(\mathrm{K}_{2} \mathrm{Cr}_{2} \mathrm{O}_{7}\right)$. penggunaan kapur juga mengakibatkan kenaikan $\mathrm{pH}$, sehingga limbah batk dengan pewarna alami ini mempunyai $\mathrm{pH}$ sekitar 9. Mordan berupa gula jawa juga sering digunakan oleh pengrajin batik di desa Wukirsari.

Tabel 1. Sifat kimiawi limbah batik pewarna alami K

\begin{tabular}{llll}
\hline \multirow{2}{*}{ Paramater } & \multicolumn{3}{c}{ Limbah batik menggunakan pewarna } \\
\cline { 2 - 4 } & Indigo & Mahoni & Jolawe \\
\hline BOD $(\mathrm{ppm})$ & 1585 & 2870 & 2430 \\
$\mathrm{COD}(\mathrm{ppm})$ & 4028 & 8345 & 7650 \\
$\mathrm{pH}$ & 9,0 & 8,5 & 9,4 \\
$\mathrm{BO}(\%)$ & 7,13 & 7,23 & 7,74 \\
$\mathrm{Al}(\mathrm{ppm})$ & 3,431 & 2,32 & 3,11 \\
$\mathrm{Fe}(\mathrm{ppm})$ & 1,020 & 0,75 & 2,10 \\
$\mathrm{Ca}(\mathrm{ppm})$ & 4,56 & 4,86 & 5,01 \\
$\mathrm{Cr}$ total $(\mathrm{ppm})$ & 0,21 & 0,16 & 0,18 \\
& & &
\end{tabular}

Nilai BOD dan COD limbah tinggi. Hal ini karena dalam proses pembatikan digunakan lilin/malam untuk mengeblok kain sehingga pada saat proses pewarnaan bagian kain yang terblok tidak akan terwarnai oleh pewarna yang tidak dikehendaki. Setelah proses pewarnaan selesai, lilin yang menempel selanjutnya dilorot menggunakn air panas dengan ditambah air tapioka (Ruwandi dan Suharno, 2000). Oleh sebab itu maka kadar bahan organik limbah termasuk dalam kategori tinggi. Penggunaan gula jawa sebagai mordan juga menyumbang tingginya kadar bahan organik dalam limbah.

Penelitian ini dilakukan dengan menggunakan contoh tanah yang berasal dari desa Wukirsari. Jenis tanahnya adalah Latosol. Contoh tanah mempunyai kadar bahan organik rendah, $\mathrm{pH}$ sedikit masam. Penambahan limbah meningkatkan $\mathrm{pH}$ tanah sehingga menjadi mendekati netral (Tabel 3). Jumlah bakteri sekitar $10^{6} \mathrm{sel} / \mathrm{g}$ tanah. Jumlah bakteri penambat nitrogen maupun pelarut fosfat dalam tanah masing-masing mencapai sekitar $10^{4} \mathrm{sel} / \mathrm{g}$ tanah (Tabel2).

Tabel 2. Sifat tanah yang digunakan dalam penelitian

\begin{tabular}{ll}
\hline Parameter yang dianalisis & Jumlah \\
\hline Bahan organik & $1,9 \%$ \\
$\mathrm{pH}$ & 5 \\
Mikrobia total & $1,7 \times 10^{6} \mathrm{sel} / \mathrm{g}$ \\
Mikrobia penambat nitrogen & $2,8 \times 10^{4} \mathrm{sel} / \mathrm{g}$ \\
Mikrobia pelarut fosfat & $6,0 \times 10^{4} \mathrm{sel} / \mathrm{g}$ \\
\hline
\end{tabular}

Tabel 3. $\mathrm{pH}$ tanah setelah ditambah dengan limbah

\begin{tabular}{cc}
\multicolumn{2}{c}{ campuran } \\
\hline Konsentrasi Limbah $(\%)$ & $\mathrm{pH}\left(\mathrm{H}_{2} \mathrm{O}\right)$ \\
\hline 0 & 5 \\
50 & 5.5 \\
100 & 6.7 \\
\hline
\end{tabular}

Sebelum diaplikasikan ke dalam tanah, dilakukan analisis terhadap populasi bakteri yang terdapat dalam masing-masing limbah pewarna alami dari jolawe, mahoni, indigo dan campuran (Gambar 1). Jumlah bakteri total dalam limbah berkisar antara 2,3 $105 \mathrm{sel} / \mathrm{ml}$ atau log (10) 5,36 sampai dengan 7,9 $105 \mathrm{sel} / \mathrm{ml}$ atau $\log$ (10) 5,89, sedangkan jumlah bakteri penambat nitrogen berkisar antara $\log$ (10) 4,11 sampai dengan $\log (10)$ 4,65, dan jumlah bakteri pelarut fosfat berkisar antara log (10) 3,48 sampai dengan log (10) 4,95.

Pengujian viabilitas sel bakteri total, penambat nitrogen dan pelarut fosfat dilakukan dalam contoh tanah yang ditambah limbah hasil pewarnaan menggunakan jolawe, mahoni dan indigo hingga kelembabannya mencapai $75 \%$ WHC. Perubahan jumlah sel bakteri total, bakteri penambat nitrogen dan bakteri pelarut fosfat selama tiga minggu inkubasi pada contoh tanah yang ditambah limbah batik pewarna berturut-turut disajikan pada gambar 2, 3 dan 4, sedangkan persamaan regresi antara waktu inkubasi (sumbu $\mathrm{x}$ ) dengan perubahan jumlah sel (sumbu y) dapat dilihat pada tabel 4,5 dan 6 .

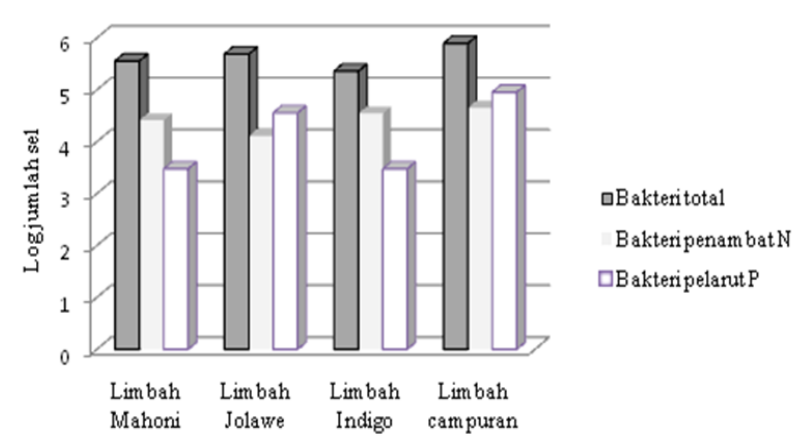

Gambar 1. Populasi bakteri dalam Limbah Pewarnaan Batik menggunakan Jolawe, Mahoni, Indigo, dan Campuran

Jumlah bakteri dalam limbah relatif tinggi, lebih dari $10^{3} \mathrm{sel} / \mathrm{ml}$ limbah. Hal ini menunjukkan bahwa limbah tidak mengandung bahan yang bersifat toksik, seperti logam berat. Demikian pula dengan jumlah bakteri penambat nitrogen dan pelarut fosfat. Bakteri pelarut fosfat yang terdapat dalam limbah mempunyai kemampuan pelarutan yang tinggi (Gambar tidak dicantumkan). Zone jernih yang ditimbulkan di sekeliling koloni mempuanyai diameter yang lebar dibandingkan dengan diameter koloni bakterinya.

Pengujian viabilitas sel bakteri total, penambat nitrogen dan pelarut fosfat dilakukan dalam contoh tanah yang ditambah limbah hasil pewarnaan menggunakan jolawe, mahoni dan indigo hingga kelembabannya mencapai $75 \%$ WHC. Perubahan jumlah sel bakteri total, bakteri penambat nitrogen dan bakteri pelarut fosfat selama tiga minggu inkubasi pada contoh tanah yang ditambah limbah batik pewarna berturut-turut disajikan pada gambar 2, 3 dan 4, sedangkan persamaan regresi antara waktu inkubasi (sumbu $\mathrm{x}$ ) dengan perubahan jumlah sel (sumbu y) dapat dilihat pada tabel 3,4 dan 5 . 

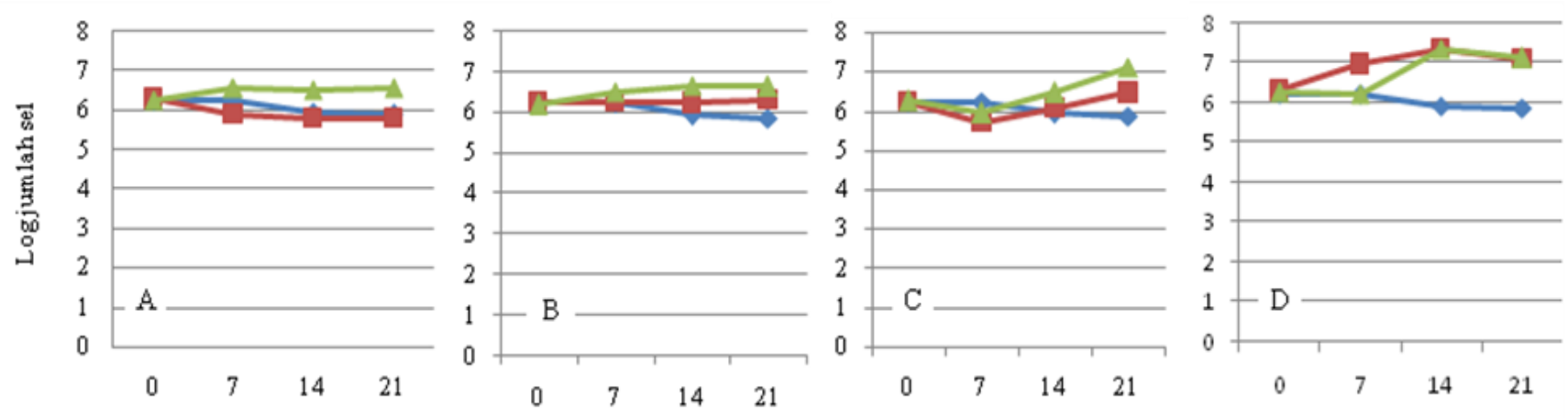

Waktu inkubasi (hari)

Gambar 2. Perubahan Jumlah Sel bakteri Total dalam Tanah yang ditambah dengan Limbah Pewarna Jolawe (A), Mahoni (B), Indigo (C) dan Campuran (D) pada kadar masing-masing 0\%( $\diamond), 50 \%(\square)$ dan $100 \%(\Delta)$.

Tabel 4. Persamaan regresi pertumbuhan bakteri total dalam tanah yang ditambah dengan limbah selama inkubasi 21 hari

\begin{tabular}{ll}
\hline Jenis limbah & Persamaan \\
\hline Jolawe 0\% & $\mathrm{y}=-0,137 \mathrm{x}+6,407$ \\
Jolawe 50\% & $\mathrm{y}=-0,151 \mathrm{x}+6,324$ \\
Jolawe 100\% & $\mathrm{y}=0,084 \mathrm{x}+6,267$ \\
\hline Mahoni 0\% & $\mathrm{y}=-0,137 \mathrm{x}+6,407$ \\
Mahoni 50\% & $\mathrm{y}=0,016 \mathrm{x}+6,231$ \\
Mahoni100\% & $\mathrm{y}=0,149 \mathrm{x}+6,125$ \\
\hline Indigo 0\% & $\mathrm{y}=-0,137 \mathrm{x}+6,407$ \\
Indigo 50\% & $\mathrm{y}=0,104 \mathrm{x}+5,856$ \\
Indigo 100\% & $\mathrm{y}=0,304 \mathrm{x}+5,676$ \\
\hline Campuran 0\% & $\mathrm{y}=-0,137 \mathrm{x}+6,407$ \\
Campuran 50\% & $\mathrm{y}=0,279 \mathrm{x}+6,235$ \\
Campuran 100\% & $\mathrm{y}=0,367 \mathrm{x}+5,824$ \\
\hline
\end{tabular}
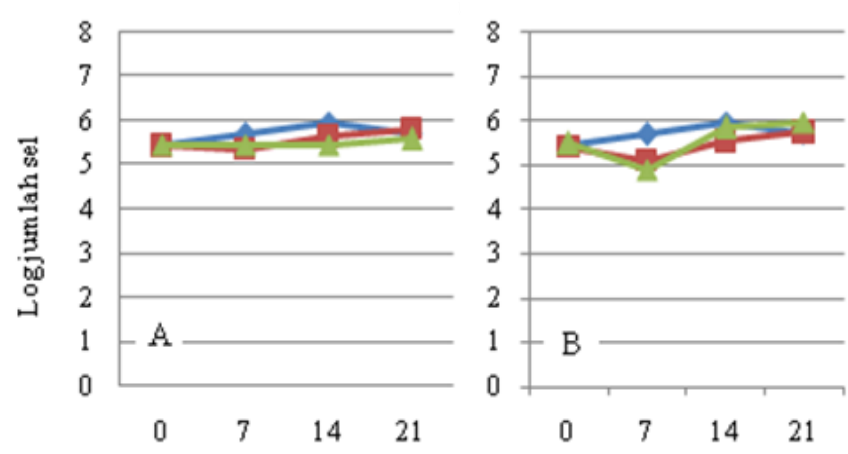

Waktu inkubasi (hari)
Setelah 21 hari inkubasi, jumlah sel bakteri total dalam tanah yang ditambah dengan limbah batik pewarna jolawe, mahoni, Indigo maupun campuran lebih tinggi daripada jumlahnya dalam tanah yang tidak ditambah limbah (Gambar 2). Koefisien persamaan regresi pertumbuhan bakteri total dalam tanah terutama yang ditambah dengan limbah batik pewarna jolawe, mahoni, Indigo maupun campuran $100 \%$ bernilai positip dan lebih tinggi daripada koefisien regresi dalam tanah yang tidak ditambah dengan limbah (tabel 3). Berdasarkan Keputusan Menteri KLH no.03/MENKLH/H/1991 tentang baku mutu air limbah industri, parameter logam menunjukkan bahwa limbah termasuk dalam kategori baik-sedang serta mempunyai kandungan bahan organik yang tinggi. Hal ini berpengaruh positip terhadap bakteri total tanah.
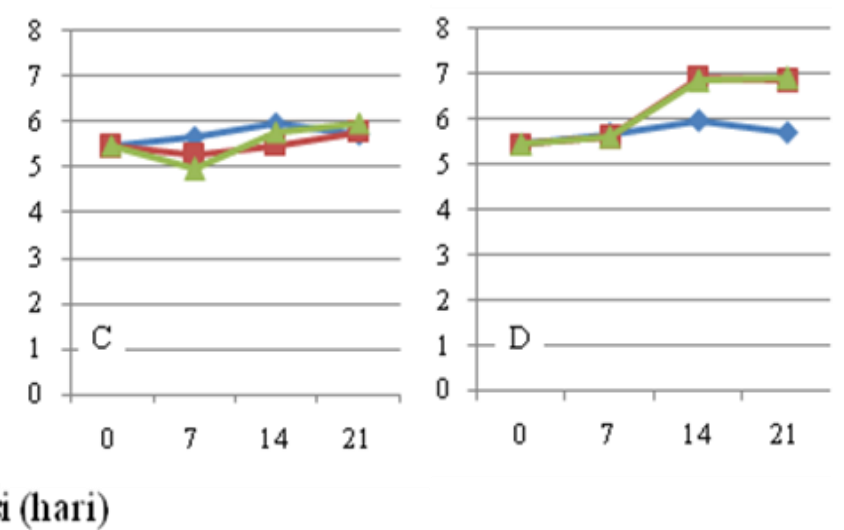

Gambar 3. Perubahan Jumlah Sel bakteri Penambat Nitrogen dalam Tanah yang ditambah dengan Limbah Pewarna Jolawe (A), Mahoni (B), Indigo (C) dan Campuran (D) pada kadar masing-masing 0\% ( $\diamond), 50 \%$ ( $\square)$ dan $100 \%(\Delta)$. 
Tabel 5. Persamaan regresi pertumbuhan bakteri penambat nitrogen dalam tanah yang ditambah dengan limbah selama inkubasi 21 hari

\begin{tabular}{ll}
\hline \multicolumn{1}{c}{ Jenis limbah } & Persamaan \\
\hline Jolawe $0 \%$ & $\mathrm{y}=0,130 \mathrm{x}+5,317$ \\
Jolawe $50 \%$ & $\mathrm{y}=0,141 \mathrm{x}+5,199$ \\
Jolawe $100 \%$ & $\mathrm{y}=0,040 \mathrm{x}+5,386$ \\
\hline Mahoni $0 \%$ & $\mathrm{y}=0,130 \mathrm{x}+5,317$ \\
Mahoni $50 \%$ & $\mathrm{y}=0,145 \mathrm{x}+5,084$ \\
Mahoni100\% & $\mathrm{y}=0,245 \mathrm{x}+4,937$ \\
\hline Indigo 0\% & $\mathrm{y}=0,130 \mathrm{x}+5,317$ \\
Indigo 50\% & $\mathrm{y}=0,121 \mathrm{x}+5,193$ \\
Indigo $100 \%$ & $\mathrm{y}=0,234 \mathrm{x}+4,955$ \\
\hline Campuran $0 \%$ & $\mathrm{y}=0,130 \mathrm{x}+5,317$ \\
Campuran 50\% & $\mathrm{y}=0,551 \mathrm{x}+4,827$ \\
Campuran $100 \%$ & $\mathrm{y}=0,558 \mathrm{x}+4,817$ \\
\hline
\end{tabular}
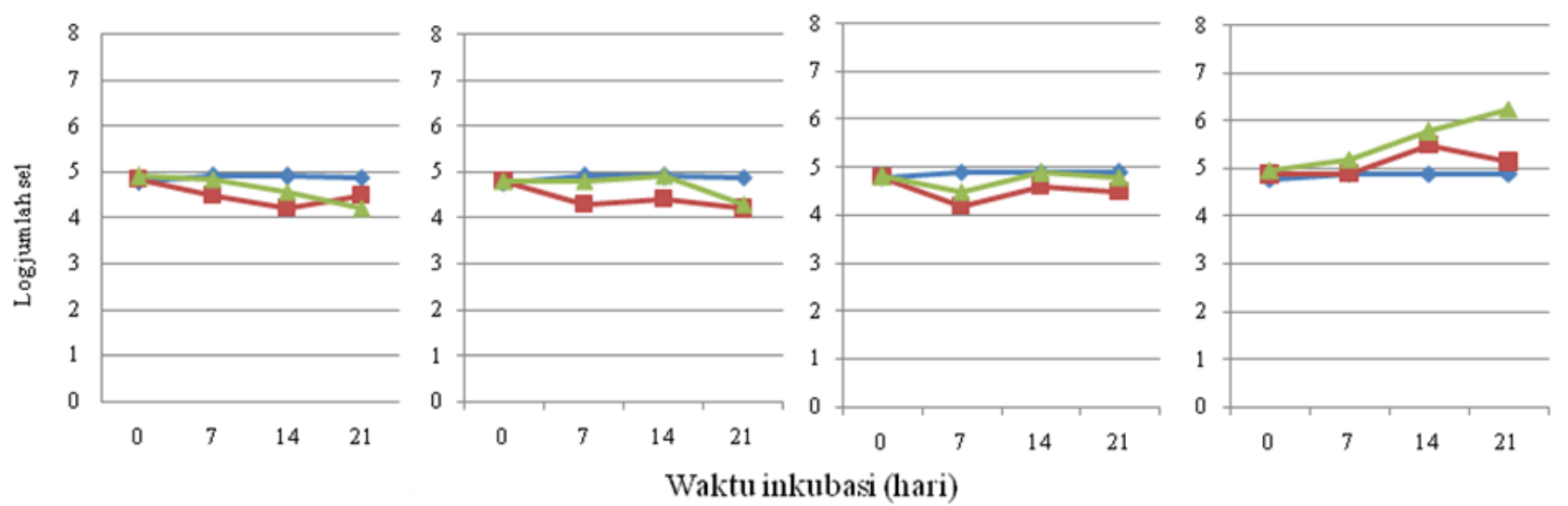

Seperti halnya pada bakteri total, pada umumnya limbah batik pewarna alami berpengaruh positip terhadap bakteri penambat nitrogen dalam tanah. Koefisien regresi persamaan pertumbuhan bakteri dalam tanah yang ditambah limbah mempunyai nilai yang lebih tinggi daripada pertumbuhan bakteri tersebut dalam tanah yang tidak ditambah dengan limbah. Keberadaan seyawa logam maupun bahan organik dan aktif yang terdapat dalam pewarna alami batik tidak berdampak negatif pada bakteri penambat nitrogen dalam tanah.

Gambar 4. Perubahan Jumlah Sel bakteri Pelarut Fosfat dalam Tanah yang ditambah dengan Limbah Pewarna Jolawe (A),

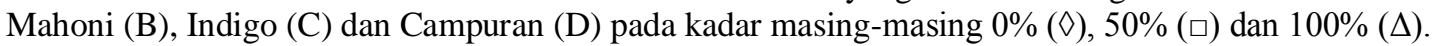

Tabel 6. Persamaan regresi pertumbuhan bakteri pelarut fosfat dalam tanah yang

ditambah dengan limbah selama inkubasi 21 hari

\begin{tabular}{ll}
\hline \multicolumn{1}{c}{ Jenis limbah } & Persamaan \\
\hline Jolawe 0\% & $\mathrm{y}=0,030 \mathrm{x}+4,789$ \\
Jolawe 50\% & $\mathrm{y}=-0,137 \mathrm{x}+4,485$ \\
Jolawe 100\% & $\mathrm{y}=-0,238 \mathrm{x}+5,223$ \\
\hline Mahoni 0\% & $\mathrm{y}=0,030 \mathrm{x}+4,780$ \\
Mahoni 50\% & $\mathrm{y}=-0,171 \mathrm{x}+4,861$ \\
Mahoni100\% & $\mathrm{y}=-0,138 \mathrm{x}+5,055$ \\
\hline Indigo 0\% & $\mathrm{y}=0,130 \mathrm{x}+5,317$ \\
Indigo 50\% & $\mathrm{y}=-0,047 \mathrm{x}+4,627$ \\
Indigo 100\% & $\mathrm{y}=0,029 \mathrm{x}+4,622$ \\
\hline Campuran 0\% & $\mathrm{y}=0,130 \mathrm{x}+5,317$ \\
Campuran 50\% & $\mathrm{y}=0,137 \mathrm{x}+4,759$ \\
Campuran 100\% & $\mathrm{y}=0,558 \mathrm{x}+4,817$ \\
\hline
\end{tabular}

Berbeda dengan bakteri total dan bakteri penambat nitrogen, penambahan limbah batik pewarna alami berdampak negatip terhadap bakteri pelarut fosfat dalam tanah, kecuali pengaruh limbah batik pewarna campuran. Setelah 21 hari inkubasi, jumlah bakteri pelarut fosfat dalam tanah yang ditambah limbah batik pewarna alami jolawe, indigo maupun mahoni lebih rendah dibandingkan dengan jumlah bakteri pelarut fosfat dalam tanah yang tidak ditambah limbah, kecuali tanah yang ditambah degan limbah campuran. Koefisien korelasi persamaan regresi pertumbuhan bakteri pelarut fosfat dalam tanah yang ditambah masing-masing limbah jolawe, mahoni, maupun indigo bernilai negatip dan lebih rendah dari pada nilainya dalam tanah yang tidak ditambah limbah. Namun demikian, pada tanah yang ditambah limbah campuran, nilai koefisien korelasinya lebih tinggi dibandingkan nilainya dalam tanah yang tidak ditambah limbah (Tabel 6).

Tabel 7. Kadar flavanoid dan fenolik limbah batik pewarna alami

\begin{tabular}{|l|l|l|l|l|}
\hline \multirow{2}{*}{ Parameter } & \multicolumn{4}{|c|}{ Limbah batik menggunakan pewarna } \\
\cline { 2 - 5 } & Campuran & Indigo & Mahoni & Jolawe \\
\hline $\begin{array}{l}\text { Flavanoid } \\
(\%)\end{array}$ & 0,70 & 0,14 & 0,18 & 0,22 \\
\hline Fenolik & 1,64 & 0,22 & 0,18 & 0,22 \\
\hline
\end{tabular}

Secara umum, limbah pewarnaan batik menggunakan jolawe memberi pengaruh paling kecil terhadap viabilitas bakteri tanah, bahkan berpengaruh paling negatif terhadap bakteri pelarut fosfat. Sebaliknya limbah batik dengan 
pewarnaan campuran berpengaruh paling baik terhadap komunitas bakteri total, bakteri penambat nitrogen maupun bakteri pelarut fosfat dalam tanah. Limbah campuran mampu meningkatkan viabilitas komunitas bakteri tanah, mungkin karena komposisinya yang beragam.

Zat warna alam sudah digunakan sejak jaman dulu untuk mewarnai tekstil. Zat warna alam dapat diperoleh dari hasil ekstrak berbagai tumbuhan seperti: akar, kayu, daun, biji, ataupun bunga (Aminoddin and Haji, 2010). Zat pewarna alam dalam industri batik di Wukirsari pada umumnya diperoleh dari hasil ekstrak berbagai bagian tumbuhan seperti akar, kayu, daun, biji ataupun bunga. Pewarna yang paling sering digunakan adalah ekstrak jolawe, mahoni dan indigo. Pewarna lain yang juga digunakan adalah: daun pohon nila (indofera), kulit pohon soga tingi (Ceriops candolleana arn), kulit soga jambal (Pelthophorum ferruginum), Secang (Caesalpinia sappan, Linn), tegeran (Maclura chocinensis), dan nangka (Artocarpus heterophyllus). Secara kimiawi pewarna alami merupakan senyawa poliaromatis berbasis benzen, berupa indigoid, anthraquinon dan derivatnya, senyawa flavonoid, senyawa fenolik, tanin, anthraquinoid, di-hydropyrans, serta Anthocyanidins. Fenol merupakan senyawa yang berasal dari tumbuhan, terdiri atas beberapa strukturdengan ciri khas berupa cincin aromatis yang mengandung satu atau dua gugus hidroksil. Senyawa fenol dikenal bersifat antiseptik karena mampu membunuh sejumlah bakteri karena merusak membran sitoplasma dan protein. Flavonoid banyak terdapat dalam semua bagian tumbuhan. Flavonoid merupakan golongan polifenol sehingga memiliki sifat kimia seperti fenol. Beberapa diantara senyawa tersebut di atas bersifat menghambat pertumbuhan jamur dan bakteri, sehingga sering digunakan sebagai antibiotik alami (Khan et al., 2003; Chengaiah et al., 2010). Tanaman jolawe, mahoni maupun indigo sering digunakan sebagai obat tradisional di beberapa negara termasuk indonesia.

Hasil analisis terhadap kadar flavanoid dari limbah pewarnaan menggunakan jolawe, mahoni, indigo maupun campuran berturut turut sebesar $0,22 \% ; 0,18 \%, 0,22 \%$, dan 0,70 , sedangkan kadar fenoliknya mencapai berturut-turut sebesar $0,22 \%$; $0,18 \%, 0,14 \%$, dan 1,64\%. Jumlah fenolik dan flavonoid pada limbah campuran paling tinggi. Semakin tinggi kadar fenolik maupun flavonoid, warna limbah semakin gelap. Nampaknya senyawa fenolik maupun flavonoid dalam limbah tidak berpengaruh terhadap komunitas bakteri tanah. Hal ini dapat terjadi karena tidak semua mikrobia tanah terhambat pertumbuhannya oleh ekstrak tanaman, ekstraksi untuk pewarna batik menggunakan air, atau kadar senyawa fenolik maupun flavanoid dalam limbah relativ rendah. Albayrak et al. (2010), dalam penelitiannya menggunakan metode difusi agar dengan konsentrasi ekstrak fenolik dari 1 sampai dengan 10\%, menunjukkan bahwa tidak semua bakteri terhambat pertumbuhannya oleh senyawa fenolik. Dari 12 spesies bakteri yang diuji, enam di antaranya terhambat pertumbuhannya oleh senyawa fenolik ekstrak dari tanaman, sedangkan enam spesies lainnya tidak terhambat. Beberapa penelitian menunjukkan bahwa pada umumnya pengujian aktivitas ekstrak tanaman obat sehingga bersifat antimikrobia, dilakukan dengan menggunakan pengekstrak berupa metanol atau etanol. Efek antimikrobia ekstrak tanaman obat tersebut tidak bersifat antimikrobia bagi semua jenis mikrobia (Elizabeth, 2005; Ali et al., 2011; Bhurat et al., 2011; Swadhini, 2011; Mallik and Banik, 2012; Nour et al., 2012; Eid et al., 2013; Jinukuti and Giri, 2013). Hasil penelitian Swadhini (2011) menunjukkan bahwa ekstrak tanaman obat menggunakan air tidak berpengaruh terhadap penghambatan mikrobia yang diuji.

Keberadaan bahan organik limbah mampu memacu pertumbuhan bakteri tanah. Namun demikian limbah mengandung bahan organik yang berasal dari malam/lilin, amilum dan pewarna alam. Struktur kimiawi dari malam/lilin dan amilum jauh lebih sederhana dibandingkan dengan pewarna alam. Apabila senyawa pewarna bercampur dengan malam dan amilum, mikroorganisme cenderung memanfaatkan senyawa yang lebih sederhana. Hal ini memungkinkan bahwa semakin lama terjadi akumulasi senyawa pewarna di alam, sehingga suatu saat akan menimbulkan masalah Sejumlah 14 isolat bakteri berhasil diperoleh peneliti. Masing-masing isolat mampu tumbuh baik dalam limbah, namun semua isolat yang diuji tidak mampu melakukan dekolorisasi terhadap limbah (data tidak dicantumkan). Di samping itu, meskipun limbah batik pewarna alam bersifat aman bagi mikroorganisme tanah, namun warna kecoklatan limbah secara estetis kurang baik, karena memiliki warna kecoklatan. Dengan demikian upaya penanganan limbah secara optimal perlu dilakukan.

\section{Daftar Pustaka}

Noh, D.O., Kim, S.H. \& Gilliland, S.E., 1997, Incorporation of cholesterol into the cellular membrane of Lactobacillu acidphilus, Jurnal Exergy, Vol.2 No.1, Juni: 07-13.

Ali1, M.A.; Sayeed; Islam, M. S.; Yeasmin, M. S.; Khan, G. R. M. A. M. and Muhamad, I. I. 2011. Physicochemical and antimicrobial properties of Trichosanthes anguina and Swietenia mahagoni seeds. Bull. Chem. Soc. Ethiop. 2011, 25(3), 427-436

Albayrak1,S., Aksoy1, A., Sağdic, O., Budak, U. 2010. Phenolic compounds and antioxidant and antimicrobial Turk J Biol. 34: 463-473. c TUBITAK doi:10.3906/biy-0901-4

Aminoddin and Haji. 2010. Functional Dyeing of Wool with Natural Dye Extracted from Berberis vulgaris Wood and Rumex hymenosepolus Root As Biomordant. Iran J. Chem. Chem. Eng., 29(3).

Atanassova, M. And Christova-Bagdassaria, V. 2009. Determination of tannins content by tetrimetric method for comparison of different plant spesies. $J$ of the University of Chemical Technology and metallurgy, 44:413-415

Baishya D., Talukdar J. And Sandhya S. 2012. Cotton Dying with Natural Dye Extracted from Flower of Bottlebrush (Callistemon citrinus). Universal Journal 
of Environmental Research and Technology. 2: 377382.

Bhurat, M. R.; Bavaskar, S. R.; Agrawal, A. D.; Bagad, Y. M.. 2011. Swietenia mahagoni Linn. - a phytopharmacological Review. Asian J. Pharm. Res.1: $1-4$.

Carlsen, S.C.K.; Pedersen, H.A.; Spliid, N.H and Fomsgaard, I.S. 2012. Fate in Soil of Flavonoids Released fromWhite Clover (Trifolium repens L.). Applied and Environmental Soil Science. Article ID 743413. doi:10.1155/2012/743413

Chang, C.C.; Yang, M.; Wen, H.; Chern, J. 2002. Estimation of Total Flavonoid Content in Propolis by Two Complementary Colorimetric Methods, Journal of Food and Drug Analysis, 10:178-182

Chengaiah, B., Rao, K.M.; Kumar, K.M.; Alagusundaram, M.; Chetty, C. M. 2010. Medicine importance of natural dyes. A Review. International Journal of Pharm Tech Research. 2:144-154

Chet, Ng W. 2009. Total phenolic and total flavonoids content of pitaya peels by water extration. A thesis Faculty of Chemical and Natural Resources Engineering Universiti Malaysia Pahang.

Eid, A. M. M.; Elmarzugi, M. A. and El-Enshasy, H. A. 2013. A review on the phytopharmacological effect of Swietenia macrophylla. Int J Pharm Pharm Sci. 5: 4753.

Elizabeth, K. M. 2005. Antimicrobial activity of Terminalia bellerica. Indian Journal of Clinical Biochemistry. 5: 150-153.

Huo, L. , Lu, r., Li, P., Liao, Y., Chen,R. , Deng, C., Lu, C., Weia, X., and Lia, Y. 2011. Antioxidant activity, total phenolic, and total flavonoid of extracts from the stems of Jasminum nervosum Lour. Grasas y aceites, 62:149154, 2011, issn: 0017-3495, doi: 10.3989/gya.066810.
Jinukuti, M. G. and Giri, A. 2013. Antimicrobial activity of aqueous extract of Terminalia chebula Retz. Recent Research in Science and Technology. 5: 46-49.

Nour, A. H.; Sandanasamy, J.A/P and Yusoff, M. M. 2012. Antibacterial Activity of Different Extracts of Swietenia Macrophylla King. 13th Medicinal and Aromatic Plants Seminar 2012 (MAPS2012), 25-26 September 2012, Kuala Lumpur, Malaysia.

Prabhu, K. H. and Bhute, A. S. 2012. Plant based natural dyes and mordnats: A Review. J. Nat. Prod. Plant Resour., 2012, 2 (6):649-664

Rodríguez,H., and Fraga, R. 1999. Phosphate solubilizing bacteria and their role in plant growth promotion. Biotechnology Advances 17: 319-339

Ruwandi dan Suharno, 2000, Teknologi Pewarnaan Batik dengan Warna Sintetis dan Alam. Materi Diklat Pendidikan Non Gelare Program DUE-Like pada tanggal 22-27 Agustus 2000 di Balai Besar Penelitian dan Pengembangan Industri Kerajianan dan Batik Yogyakarta.

Samanta, A.K. and Konar, A. Dyeing of Textiles with Natural Dyes. www.intechopen.com. Diunduh 15 Juli 2013.

Saharan, B. S. and Nehra, V. 2011. Plant Growth Promoting Rhizobacteria: A Critical Review. Life Sciences and Medicine Research, Volume 2011: LSMR-21

Swadhini, S.P. 2011. Phytochemical Phytochemical screening and antimicrobial activity of five medicinal plants against Myrothecium sp. International Journal of Pharma and Bio Sciences. 